\title{
English walnut rootstocks help avoid blackline disease, but produce less than 'Paradox' hybrid
}

\author{
Joseph A. Grant \\ Gale H. McGranahan \\ $\nabla$
}

While 'Paradox' hybrid seedlings are often the rootstocks of choice for California walnut orchards, there is a resurgence of interest in using English walnut seedlings because walnut blackline disease, which is endemic in many California walnut production districts, does not affect them. We compared the growth and productivity of walnuts on English rootstocks from a variety of sources to those on Paradox rootstock. The growth and productivity of 'Chandler' walnut trees were similar among trees on seedling English rootstocks in one trial, but trees on English rootstocks were smaller and had lower production than Paradox hybrid-rooted trees in the other.

\section{California's first walnut trees and orchards were planted during the} Spanish mission period (around 1800), using seedlings of early varieties of Persian or English walnut (Juglans regia) chosen for their superior growth and nut quality. Since the 1890s, walnut trees in California have been propagated by grafting or budding desired cultivars onto rootstocks chosen for their adaptation to different physical, chemical or biological soil conditions at individual orchard sites. From the early to mid20th century, seedlings of Northern California black walnut (Juglans hindsii) were used as rootstocks because they grew vigorously and were more tolerant of saline and saturated soil and more resistant to soil-borne pests than English walnut seedlings.

Since the 1950s, 'Paradox' hybrid seedlings have supplanted black and English walnut as rootstocks of choice for California orchards, though black walnut (J. hindsii and others) is still
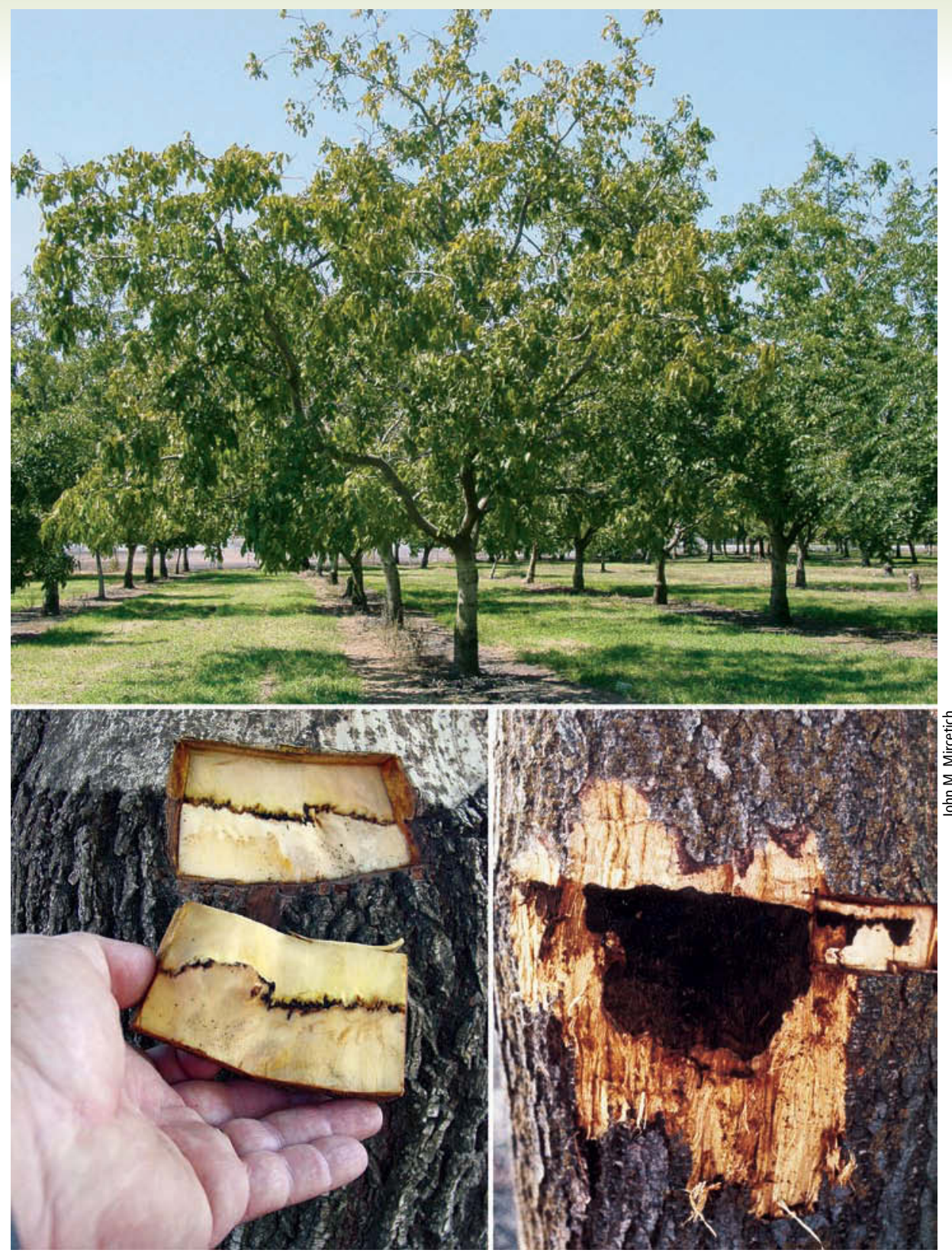

Blackline-infected trees on, above left, black walnut, and, above right, 'Paradox' rootstocks are slowly girdled by the death of rootstock tissue at the graft union. Top, over time, walnut trees with blackline decline in vigor, leading to dieback of branches and, ultimately, death of the tree. Trees on English rootstocks develop no graft union symptoms and escape the debilitating effects of blackline infection.

used occasionally. Paradox seedlings are hybrids of black and English walnuts, and the rootstocks are grown by nurseries using seed nuts collected from black walnut trees, particularly J. hindsii (Potter et al. 2002) pollinated by English walnut pollen. Paradox-rooted trees grow more vig- orously than those on black or English walnut rootstocks, are more resistant to Phythophthora root and crown rot disease, and are more tolerant of lesion nematode (Pratylenchus vulnus), both of which are widely distributed and problematic in California orchards (Browne et al. 1977; McGranahan and Catlin 1987; 


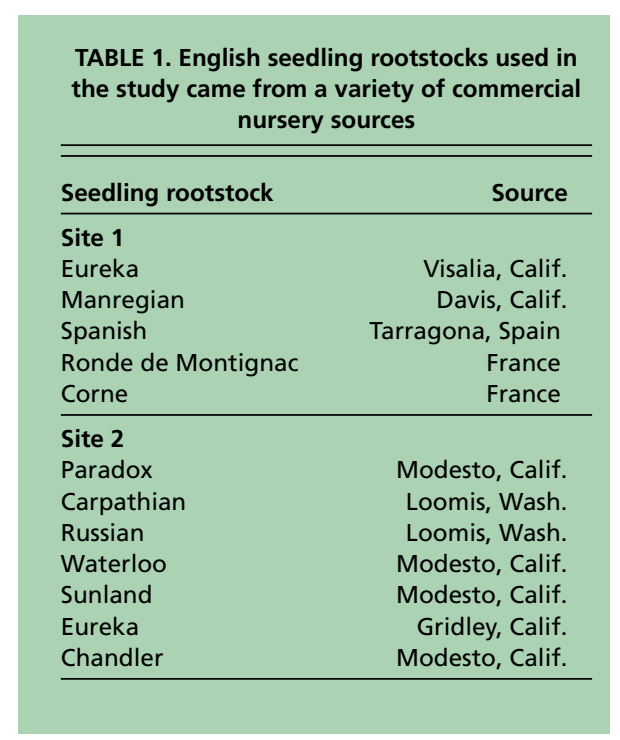

Serr and Rizzi 1964). Because of their generally poor performance, both in controlled experiments and limited commercial orchard use, English seedlings are now used only occasionally as walnut rootstocks in California.

The recent resurgence of interest in using English walnut seedlings as rootstocks in California is a result of the discovery in the 1970s that walnut blackline disease, caused by cherry leafroll virus (CLRV), was endemic in many California walnut production districts. CLRV infection kills tissue at the graft union of trees grown on black walnut and Paradox rootstocks, but not those on English walnut rootstock because it is naturally tolerant of CLRV. This reaction gradually girdles and kills black walnut- and Paradox-rooted trees (Mircetich et al. 1980; Mircetich and Rowhani 1984). There is some evidence from Europe of adverse impacts due to systemic CLRV infection on the growth of English-rooted trees (Mircetich et al. 1998). But these effects are not as well documented as other disadvantages of this rootstock and, thus, are not considered detrimental enough to preclude its use where otherwise indicated.

Seedlings of 'Manregian' and 'Eureka' English walnuts have been available to California growers for many years. In the 1980s, commercial nurseries began offering seedlings from a variety of other English walnut sources in response to renewed interest stimulated by the discovery and prevalence of blackline disease. We undertook this study to compare the orchard performance of seedlings from some of these
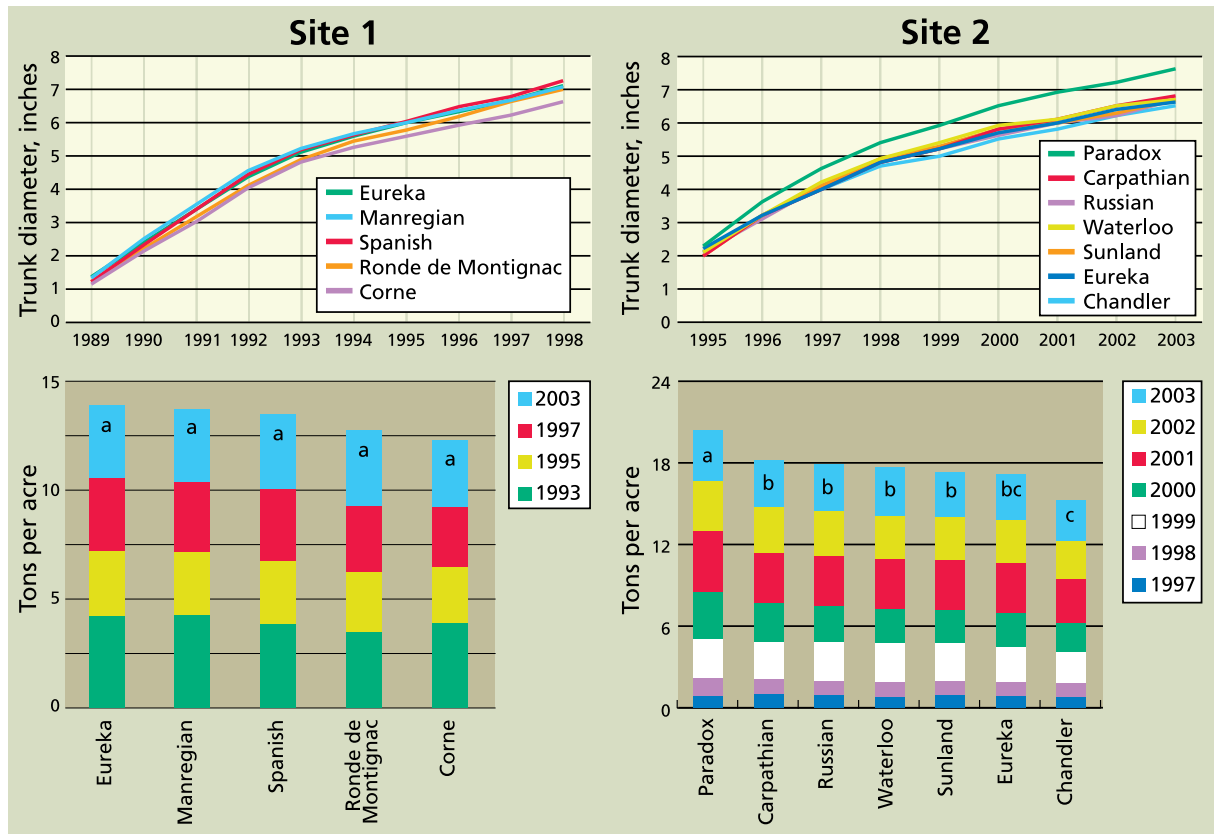

Fig. 1. Average trunk diameter (top) and nut production (bottom) of experimental trees at site 1 (left) and site 2 (right). Columns headed by common letters indicate cumulative yields that are not significantly different (Fisher's protected LSD, $P \leq 0.05$ ).

English walnut sources as rootstocks for walnuts in California. The identification of a source of English walnut with superior vigor, productivity and pest tolerance could provide walnut growers in areas of high CLRV incidence with an acceptable alternative to the hypersensitive rootstocks currently in use.

\section{Rootstock trials}

Two trials were established in a commercial walnut orchard near Linden in San Joaquin County. Soil at both test sites was Archerdale clay loam. The trials were in 12-feet-by-24-feet high-density "hedgerow" plantings, which were sprinkler-irrigated. Formerly planted to walnuts, both sites were fumigated with methyl bromide prior to planting.

Site 1 was planted in 1989 and consisted of three rows of 'Chandler' trees that had been nursery-grafted on English walnut seedlings from Manregian and Eureka from California, 'Ronde de Montignac' and 'Corne' from France, and a source collected from Tarragona, Spain. Experimental plots were within pollenizer rows planted every eighth row in a 'Vina' orchard (table 1).

Site 2 was planted in 1994 and included seedlings from Eureka, 'Waterloo', Chandler and 'Sunland' provided by a California nursery, two English walnut sources named 'Russian' and 'Carpathian' by their respective suppliers (McGranahan and Leslie 1990), and Paradox hybrid seedlings from a California nursery. Experimental plots were in five alternate rows in a solid Chandler planting.

The trials at both sites were configured as randomized complete block designs, with three 5-tree plots at site 1 and five 8 -tree plots at site 2 . Trees for both sites were nursery-propagated and planted as grafted 2-year-old trees. Nursery seedlings for both sites were tested for CLRV, and infected trees were discarded to prevent the introduction of blackline virus disease to the test orchard.

Tree growth was evaluated at both sites by annual trunk-diameter measurements made 12 inches above the graft union. Yield (in-shell, 8\% wet basis moisture) was measured at site 1 in 1993, 1995, 1997 and 2003, and at site 2 in annually from 1997 through 2003. Growth and yield data from the experimental plots were analyzed using two-way analysis of variance and Fisher's protected LSD for mean separation.

\section{Tree growth and productivity}

At site 1, there were no significant differences among English-rooted trees in annual trunk diameter or nut production (fig. 1). Similarly, at site 2, English-rooted trees from all sources were similar in trunk diameter during most of the study years (1995 
through 1998, and 2001 through 2003) (fig. 1). The only significant difference in trunk diameter recorded among English-rooted trees was in 1999 and 2000 at site 2, when trees on Chandler seedlings were smaller than those on Waterloo seedlings. In contrast, trees on Paradox seedlings had significantly larger trunk diameters than those on any of the English rootstocks from 1996 through 2003.

Individual year yields at site 2 were not significantly different among rootstocks in 1997, 1999 or 2003. Paradoxrooted trees had significantly greater yields than trees on all English rootstock sources in 2000 and 2001, and all but those on Carpathian seedlings in 1998 and Russian and Carpathian seedlings in 2002. Individual year yields were similar among English sources except for in 2000 and 2001, when Chandler-rooted trees had significantly lower yields than Carpathian-rooted trees, and in 2002, when Chandlerrooted trees yielded less than Russianrooted trees.

Cumulative yield (1997 through 2003) at site 2 was greater for Paradoxrooted trees than for those rooted on any English seedling source. The cumulative yield of Chandler-rooted trees was less than that of all other English sources except Eureka. We attribute the generally greater yields of Paradox-rooted trees and lower yields of Chandler-rooted trees to differences in tree growth and size on these rootstocks, since yield efficiency was similar among rootstocks between 1998 and 2003 (data not shown).

\section{Planning a new orchard}

Our results show that most English rootstock seedling sources produced trees with similar growth and nut production. The exception was Chandler, which produced generally smaller and less-productive trees than the other sources at site 2 . Walnut growers wishing to plant orchards on English rootstocks should avoid the use of Chandler seedlings.

No English seedling source tested at site 2 produced trees with growth and productivity as high as those of Paradox hybrids. Therefore, walnut growers needing blackline tolerance will likely incur some loss in early orchard growth

\section{Walnut blackline disease, caused by cherry leafroll virus, is endemic in many California walnut-producing districts. This has spurred renewed interest in using English walnut seedlings as rootstocks.}

and nut production as a result of planting English seedling rootstocks.

However, it remains to be determined - in this trial as well as in commercial practice - whether the growth and yield advantages of Paradox-rooted trees will be outweighed by the potentially longer life of English-rooted trees, since blackline incidence increases over the life of the orchard. In addition, because English-rooted trees are still considered more susceptible to Phytophthora root and crown rot, and to damage by lesion nematode, growers must carefully evaluate all the ramifications of their rootstock choice when planning a new orchard.

J.A. Grant is Farm Advisor, UC Cooperative Extension, San Joaquin County; and G.H. McGranahan is Pomologist, Department of Plant Sciences, UC Davis. The authors thank walnut grower Jim Ferrari of Linden for hosting these trials and the California Walnut Marketing Board for supporting them.

\section{References}

Browne LT, Brown LC, Ramos DE. 1977. Walnut rootstocks compared. Cal Ag 31(7):14-5.

McGranahan GH, Catlin PB. 1987. Juglans rootstocks. In: Rom RC, Carlson RF (eds.). Rootstocks for Fruit Crops. New York: Wiley. p 411-50.

McGranahan GH, Leslie C. 1990. Walnuts (Juglans L.). In: Moore JN, Ballington JR (eds.). Genetic Resources of Temperate Fruit \& Nut Crops. Acta Hort 290(2). Int Soc Hort Sci, Wageningen. p 907-51.

Mircetich SM, Rowhani A. 1984. The relationship of cherry leafroll virus and blackline disease of English walnut trees. Phytopath 74:423-8.

Mircetich SM, Rowhani A, Civerolo EL, Ramos DE. 1998. Blackline disease. In: Ramos DE (ed.). Walnut Orchard Management. UC ANR Pub 3373, Oakland, CA. p 233-41.

Mircetich SM, Sanborn RR, Ramos DE. 1980. Natural spread, graft transmission and possible etiology of walnut blackline disease. Phytopath 70:962-8.

Potter D, Fangyou G, Baggett S, et al. 2002. Defining the sources of Paradox: DNA sequence markers for North American walnut (Juglans L.) species and hybrids. Scientia Horticulturae 94:157-70.

Serr EF, Rizzi AD. 1964. Walnut Rootstocks. Univ Calif Agri Ext Serv Pub AXT 120.

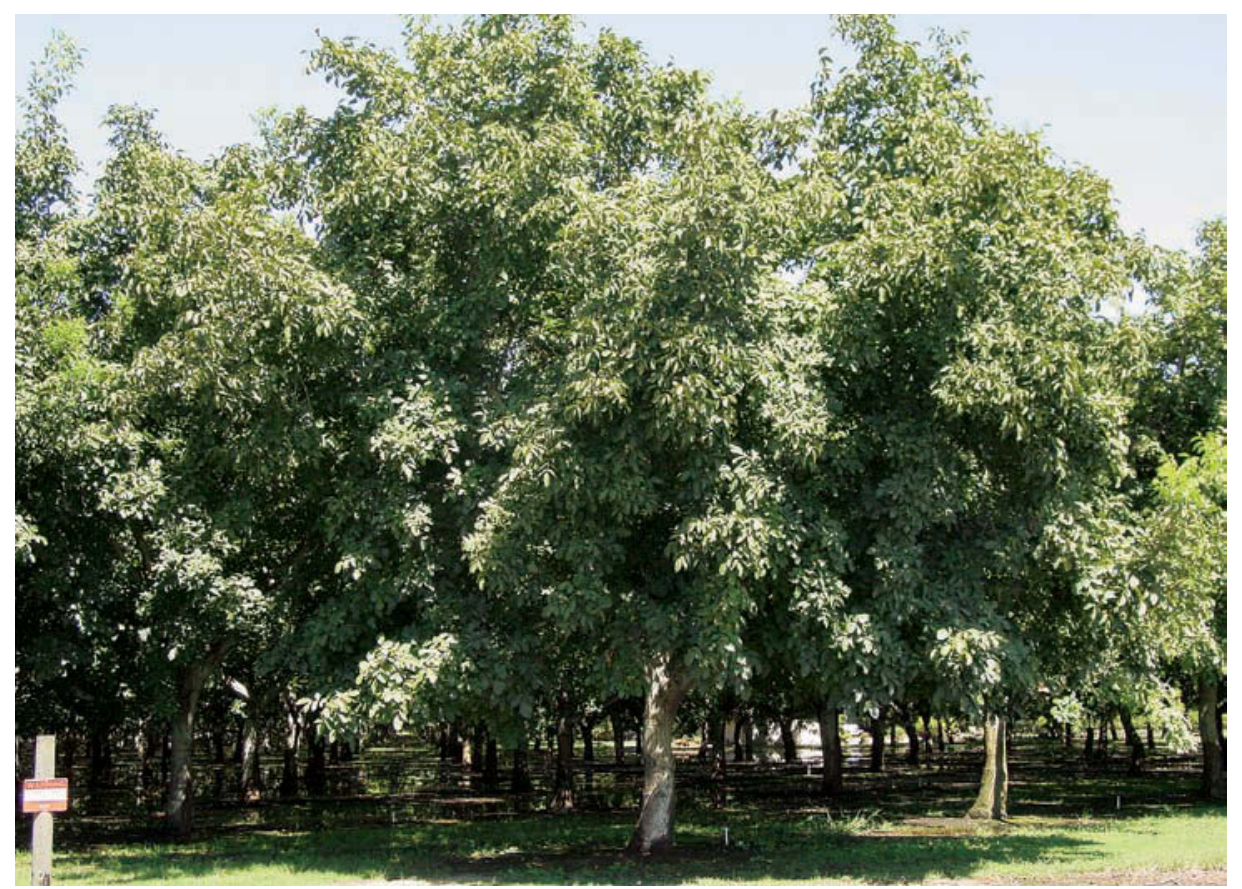

Careful rootstock selection can help to prevent blackline infection. Above, healthy walnut trees on English rootstock (variety 'Chandler') in an orchard near Linden. 